Oxana

Timofeeva

\title{
UNCONSCIOUS DESIRE FOR COMMUNISM
}

\section{Bionote}

Dr. Oxana Timofeeva is a senior research fellow at the Institute of philosophy of Russian Academy of Science (Moscow), a senior lecturer on contemporary philosophy at European University in St. Petersburg, a member of the artistic collective "Chto Delat?" ("What is to be done?"), a member of the editorial board of the journal "Stasis", and the author of books History of Animals: An Essay on Negativity, Immanence, and Freedom (Maastricht, 2009), and Introduction to the Erotic Philosophy of Georges Bataille (Moscow, 2009).

\section{Abstract}

The question of what the community should be is a question of value and what ought to be; any attempt to answer this question leads us to discordant models of social organization, to an ideological quarrel about how to rebuild humanity. The community appears as a gathering of people, large or small, but certainly different from a group, a collective, a society - in terms of its density or the character of its objectives, its anatomy or teleology. As we are told, the community is not a group, not a collective, no - and it is not a nation, not a people - but it is also not a crowd or a mass. The specter of communism hangs in the common and unappropriated air. The very name swears an oath of allegiance to the idea of the community. Communism is the society of the community, what is common and belongs to no one, but we will never agree on the subject of whether this principle coincides with or opposes democracy. Thus the specter of communism, having appeared out of the air, disperses into it as well. Communism is humanity's memory of what has not yet happened. In this way it resembles a dream - you never know when the idyll might turn into a nightmare.

Passenger pigeons used to inhabit all the territories of the US and Canada. They appeared in the sky in such thick flocks that they literally blocked the sun. It grew dark like during an eclipse. The flying birds covered the whole firmament from one horizon to the other. Pigeon dung fell from the sky like snowflakes; the endless hum of wings recalled the whistling of storm winds.

Hours went by, but the pigeons were still flying and flying, with neither the end nor the beginning of their marching column in sight. Nothing could divert this "squadron," innumerable as locusts, from its course-not shouts, not gunshots, not cannonfire. [...] 
Was it really possible to exterminate such a fantastic multitude of birds quickly? The sad fate of the passenger pigeon tells us that it is possible, if you take up this task in a clever way.

\section{(I. Akimushkin. The Tracks of Unseen Beasts ${ }^{1}$ )}

The question of the community is the question of a definition that is always lost in the succession of scholarly paradigms. Its answer follows the formula $A=B(C, D .$.$) ,$ where the community is an indifferent object among other equally indifferent objects, a washed-out stain on the scholarly picture of the world. It may be this or that, but its definition (or set of definitions) is not even a tool, let alone a weapon in this dangerous game we play with ourselves, and in which the community is one of the biggest stakes.

The question of what the community should be is a question of value and what ought to be; any attempt to answer this question leads us to discordant models of social organization, to an ideological quarrel about how to rebuild humanity. The community appears as a gathering of people, large or small, but certainly different from a group, a collective, a society - in terms of its density or the character of its objectives, its anatomy or teleology. As we are told, the community is not a group, not a collective, no - and it is not a nation, not a people - but it is also not a crowd or a mass.

1 This article was written as part of my research at Humboldt University in Berlin with the financial support of the

Alexander von Humboldt Foundation (stipend for experienced researchers). It also summarizes several outcomes of my twoyear work in the Jan van Eyck Academy in Maastricht (20102011).

Ivan Akimushkin, Sledy nevidannyx zverei (Moscow: Geografgiz, 1961).
The question of the community - they tell us - is a question about the essence of democracy, a question about the limits of human coexistence, a question about the common, about what we share with one another, beyond definitive goals, identities, advantages, fortunes, stations, ideologies, idols, ideals, fears, passions beyond everything that links us to a group, a collective, a nation, a people, and also to the crowd and the masses. As if between us there was a place for some kind of common "in general," some general-in-commonality, but at the same time not total and certainly not "totalitarian." This is a specific modality of resisting totalization, resisting the unification of an imaginary gathering under a common flag. The community, they tell us, will not march in step to the victory of any one transcendental principle. As an indeterminate and immanent multiplicity of singularities, the community is indistinguishable from the absence of community: it is unrepresentable, but nothing is possible without it, it's just like the air we breathe - common to all and belonging to no one. No one can appropriate the air.

The specter of communism hangs in the common and unappropriated air. The very name swears an oath of allegiance to the idea of the community. Communism is the society of the community, what is common and belongs to no one, but we will never agree on the subject of whether this principle coincides with or opposes democracy. Thus the specter of communism, having appeared out of the air, disperses into it as well. The name "communism" is hurriedly stuffed with the noise of discussions about the general horizon of the future, and these are filled with the noise of other discussions - about the past, about the burden we drag altogether with us toward our horizon, making it seem all the more frightening. Communism is humanity's memory of what has not yet happened. In this way it resembles a 
dream - you never know when the idyll might turn into a nightmare.

The moment when an idyll turns into a nightmare is one of those moments in the dream, when the real of our desire tries to speak. It speaks in the language of the unconscious, difficult to translate and belonging to no one. There is no "I" in this language; it is pre-personal and pre-individual, and it is with this language that the unrepresentable, anonymous multiplicity expresses itself. It is not so much an "it," or "id," in the Freudian sense, as a "they" which has not yet appeared as a gathering of people. The inhabitants of this world are animals; the dream's navel joins me to "them," those who have no faces.

The question of what a community is or what a community should be - a question of definition or necessity - is a question about people, about calculable gatherings of people, by whose efforts the original matter of democracy or communism is in the end subordinated to the forms of national or totalitarian states - at least this is what concrete historical experience teaches us. But a "they" is not a "we" - only at the level of the real of our desire, the level of affect, does the uncountable multiplicity of beasts first come into its rights. The question of the community as desire (the question of utopia) brings us back to the uncountable multiplicity of beasts, to the animal unconscious. Here there is nothing primary, original, organic, native - following "them," the paths of beasts, we return not to the origin but to that which has never been.

The idyll of the community (communism) never existed before its reality became a nightmare. The real of our desire never existed before we began to translate it from the language of the unconscious - an inarticulate language, like a beast's cry. We only know this language in translation, but indeed it only arises at the moment of translation; the original (forgotten, lost) arises through the process of translation. "They" do not exist before us by themselves, but as soon as "we" arrive, "they" are always already here, "they" were always already here: a paradoxical retrospection. The question of "we," of the community (and with them the question of communism, of democracy, of utopia) in this way becomes a question of the animal multiplicity (of the unconscious), and this is precisely how we will raise it here.

As Lacan said, the unconscious is structured like a language. The unconscious is the speech of the Other, a form of speech not ruled by the ego. ${ }^{2}$ Human subjectivity, as Lacan understands it, is the result of an appropriation of what lies "beyond" the mirror, beyond speech, what is called the outside. A human being is born prematurely, awkward, fragmented, ill prepared. But when a small child, just having learned to walk, looks in the mirror and sees his reflection, suddenly he or she guesses that this is "me." The miracle of recognizing oneself in the mirror is something like a compensation for our premature appearance in the world. ${ }^{3}$

According to Lacan, animals do not have language, and this means no unconscious, no speech of the Other to appropriate from the outside and from which to build one's integrity and singularity. What does Lacan's pigeon see in the mirror? Another pigeon, a potential

2 See, for example: Viktor Mazin, Vvedenie v Lakana ["Introduction to Lacan"] (http://www.xliby.ru/kulturologija/ vvedenie_v_lakana/p2o.php).

3 Jacques Lacan, "The Mirror Stage As Formative Of The I Function As Revealed In Psychoanalytic Experience", in Ecrits, A Selection, Trans. by Bruce Fink (New York; London, W.W. Norton \& Company), 93-100. 
sexual partner. Lacan refers to a biological experiment which "acknowledges that it is a necessary condition for the maturation of the female pigeon's gonads that the pigeon see another member of its species, regardless of its sex; this condition is so utterly sufficient that the same effect may be obtained by merely placing a mirror's reflecting field near the individual. Similarly, in the case of the migratory locust, the shift within a family line from the solitary to the gregarious form can be brought about by exposing an individual, at a certain stage of its development, to the exclusively visual action of an image akin to its own, provided the movements of this image sufficiently resemble those characteristic of its species." 4

In his essay “And Say the Animal Responded?” Jacques Derrida groups Lacan with Descartes, Heidegger, and Levinas - philosophers who draw a clear line between the human and the animal. For Derrida the very possibility of such a distinction is highly problematic as one of a series of metaphysical binary oppositions that reduce the multiplicity of beasts to a certain generic figure of the "animal," against the background of which the identity of the human is organized. This is how he discusses the passage quoted above about the pigeon: "Lacan speaks of movement from the 'solitary' to the 'gregarious' form, and not to the 'social' form, as though the difference between gregarious and social were the difference between animal and human." ${ }^{5}$

Of course, for Derrida this is a question of a particular kind of politics - an unresponsive, speechless, herdlike animality that turns out to be that point, at first glance marginal, from which all the viciousness of the

4 Ibid., 96.

5 Jacques Derrida, The Animal That Therefore I Am, trans. David Wills (New York: Fordham University Press, 2008), p. 121. repressive, totalitarian philosophical tradition suddenly opens up to one's gaze, the viciousness of the circle that marks the human, logos, and being. ${ }^{6}$ Giorgio Agamben calls the mechanism of production of this distinction the "anthropological machine," not only separating people from animals but also anthropologizing animals and bestializing people. $^{7}$

Both Agamben and Derrida are concerned with this border and the violence that occurs on the approach to it - racist violence or the violence of the apparatus toward life, toward the body. Both base their analysis of animality - an analysis of difference or a border on a deconstruction or criticism of Heidegger's project and, in particular, Heidegger's critique of humanism (according to Heidegger, humanism is not sufficiently radical because it recognizes the animality of the human - superior in some ways, for example thinking, but still an animal). ${ }^{8}$ The deconstruction of Heidegger's Destruktion follows the tracks left by beasts that must be excluded from the community. We can live with them in one house, Heidegger says, but we cannot co-exist with them and share being with them, just like we cannot share sense with them - after all, only language is the authentic house of being, while they are homeless, do not understand our language, producing only senseless noise. ${ }^{9}$

6 See, for example, Jacques Derrida, “The Ends of Man,” trans. Edouard Morot-Sir, Wesley C. Puisol, Hubert L. Dreyfus, and Barbara Reid, in Philosophy and Phenomenological Research, $30,1$.

7 See Giorgio Agamben, The Open: Man and Animal, trans. Kevin Attell (California: Stanford University Press, 2004).

8 See Martin Heidegger, "Letter on Humanism", trans. Frank A. Capuzzi, in Pathmarks (Cambridge: Cambridge University Press, 1998).

9 See, for example: Susanna Lindberg, "Heidegger's Animal," in 
While I agree with Derrida, Agamben, and other contemporary philosophers that the classic idea of the human's superiority over the animal is far from innocent, and its sustained unraveling is a matter of principal importance, I cannot deny the constitutive role of binary oppositions and their ambivalent consequences - in particular for a non-human theory of the community, of which I will risk a brief sketch in this essay. Of course, Derrida's attacks on traditional metaphysics and its reduction of the irreducible multiplicity of the animal world to one simple category of "the animal" are fair, but at the same time, as Slavoj Žižek affirms in a somewhat Hegelian vein, "the violent reduction of such a multiplicity to a minimal difference is the moment of truth." ${ }^{10}$ Žižek's idea, to put it briefly, is that precisely this minimal, theoretical binary gives birth to the truth of the human - not the truth that is officially pronounced on its side of the opposition (rational, thinking, etc.), but another truth about the non-human core of humanity. We would never have learned about this other side without the animal, what we think we are not, looming on the horizon of our knowledge about ourselves.

Yes, animals have no unconscious; they are the unconscious themselves (not so much the darkness of

Phenomenological Studies (Hamburg, 2004), 215, and also my articles: Oxana Timofeeva, "Koni v zakone: Kratkii nabrosok k filosofii zhivotnogo," [Horses in Law: A Brief Outline to the Philosophy of Animal"] Sinii divan 10-11 (2007), 80-95; idem. "Bednaia zhizn': Zootekhnik Visokovskii protiv filosofa Xaideggera," [Poot Life: Zootechnician Visokovsky Against Philosopher Heidegger"] Novoe literaturnoe obozrenie 106 (2011) 96-113; and the monograph: Oxana Timofeeva, History of Animals: An Essay on Negativity, Immanence and Freedom (Maastricht: Jan van Eyck Academy, 2012), 119-130.

10 Slavoj Zizek, Less Than Nothing: Hegel and the Shadow of Dialectical Materialism (London: Verso, 2012), 408. instincts and drives, but the language of the Other - not the possession of language but its being, which is carried to us either as noise or a cry). They have no being; they are being itself (the human is the shepherd of being, says Heidegger; and this means that being is a herd, and the call that comes from it is indistinguishable from noise or a cry). They have no community; they are community themselves (an irreducible, noisy multiplicity). I am taking account of the paradoxical aspect of this method, but I hope that the intuitions and hypotheses lying at its foundation can serve as a fragile bridge to the utopian community of beasts, about which the desire for communism communicates in its own language, so difficult to translate.

To begin I will attend to one more distinction, made by Heidegger, between the animal and the human. Namely, for him, animals are not only incapable of language, they also cannot count. ${ }^{11}$ This thesis brings us back to Lacan's pigeon, who cannot count to one. The pigeon is a real narcissist, naively believing in the reality of its reflection in the mirror. In fact, the animal world has no mirrors in contrast to gatherings of people, animal multiplicities are not formed from singularities, from egos. The pigeon and its reflection are already a couple, hinting at coitus: a visual effect is enough. People come together into gatherings - and they come one by one; animals multiply, looking at one another. Yes, they do not know how to count, and they are uncountable. Pigeons, these - as they say now in Belgium - "rats with wings," 12 gray

11 See, for example, Stuart Elden, Speaking Against Number: Heidegger, Language and the Politics of Calculation (Edinburgh University Press, 2006).

12 See, for example, these recent news about plans to euthanize urban pigeons, approved by the authorities in Brussels: http:// korrespondent.net/tech/health/1568341-vlasti-bryusselyaodobrili-plan-evtanazii-gorodskih-golubej. 
bastards of the city, block the sky with their bodies, fill the squares, and shit on the heads of monuments to the most noble and respected people.

One can count all the people living on the planet within a certain margin of error. But we could never count all the animals. Only some limited groups of specific animals can be counted if they are integrated into the economic activity of human beings (pets, livestock, rare examples of disappearing species). The economic activity of human beings, it is true, spreads across the entire living world, but to determine the number of beasts as a whole is impossible - not because there are too many of them but because they have no number. At least not such a number as what can be calculated, rationally enumerated and inventorized. Economic control of the human being over the animal world for this reason replaces the count of classifications, parsing this motley, humming multiplicity into types, species, or families.

Thus, the Book of Numbers is a kind of census of the Jewish population, a broad calculation of gatherings of people. Leviticus, which precedes it, contains among other things a classification of animals. The God of Leviticus tells the Jews which animals can be eaten or sacrificed and which cannot, which are clean and which are unclean.

We learn about one particularly radical biblical attempt at counting the animals in Genesis 5-8, the story of Noah's Ark. Regretting what he has created (since humanity has fallen into sin), God decides to exterminate all living things - the flood waters are meant to wipe all living beings from the face of the earth, apart from those taken aboard the rescue boat.

Turning to Noah, God gives his first command about the animals - take "two of every kind of flesh," "male and female:" "Of fowls after their kind, and of cattle after their kind, of every creeping thing of the earth after his kind, two of every sort shall come unto thee, to keep them alive." Here the count is a question of life or death - only those that have been counted will survive. What is disturbing about this command? Whole species remain beyond the field of vision of the ark's creator. All animals that lack sexual difference, hermaphrodites, homosexual animals, and those who reproduce themselves asexually - none of these will make it on board.

However, later God gives a new command: "of every clean beast thou shalt take to thee by sevens, the male and his female: and of beasts that are not clean by two, the male and his female. Of fowls also of the air by sevens, the male and the female; to keep seed alive upon the face of all the earth."

Why should clean animals be taken on board in sevens, and the unclean only in couples? Noah, of course, does not ask God about this, but we would have liked to ask, if we had had the opportunity. Perhaps the answer was obvious for the people of the Old Testament. The selection of animals for the ark is the most serious and important household activity, with which Noah and his family are entrusted, and here classification serves as the foundation for a headcount of cattle. Clean animals are those that can be, first, eaten, and, second, sacrificed. Most likely, besides one couple, intended for the maintenance of the species, two extra couples (and, perhaps, their offspring) formed a kind of food supply. One member of each group of seven - a single animal, with no mate, as if agamic - will be sacrificed to God as a sign of gratitude when the floodwaters recede and the boat reaches dry land.

And so the preparations are complete: "all the fountains of the great deep were broken up, and the windows of 
heaven opened. And the rain was upon the earth forty days and forty nights." Only one couple or one group of seven of every species is on board. All the rest - who have not been counted and are uncountable - are abandoned to the deep.

Is it not from this abyss that the animal unconscious is called to our memory? Our path to it lies through one more Bible story - this time from the New Testament.

In the legend of the exorcism of the Gerasene demoniac, Jesus and his disciples sail to the country of Gadara and meet a man who is possessed by devils, wears no clothes, and lives not in a house but in the tombs. The unclean spirits torture the possessed man; people bind him in chains, but he tears them off and flees into the desert. Jesus asks his name, and the man answers: "My name is Legion: for we are many." ${ }^{\prime 3}$ The legion of devils asks Jesus not to send them into the abyss but into a herd of pigs, grazing nearby. Jesus allows them to enter the bodies of the pigs after leaving the man, and the herd throws itself into a lake and drowns.

Pigs are unclean animals. Another meaning of the word "unclean" is a devil, an evil spirit. The unclean, evil spirits, the number of which fits their name - Legion - in the final analysis find a refuge (and death) in the bodies of beasts. The herd of sheep, carrying away the devils inside, recall the famous "ship of fools," particularly Michel Foucault's description of it in his History of Madness. ${ }^{14} \mathrm{He}$ refers to the medieval tradition of gathering all madmen, putting them on a boat, and sending them off on an endless voyage in the open sea.
Thus the community - the gathering of people - heals its body by excluding the dangerous, heterogeneous elements that do not participate in economic activity and do not submit to calculation. The ship of fools is Noah's Ark in reverse. Here safety is only on land, and the sea together with the ship is a symbol of the abyss (and, as Foucault reminds us, a symbol of madness).

Abandoned by the crowd of devil-beasts, man is left alone. This is the meaning of the healing procedure now he is given his name, his home, now he can again recognize himself in the mirror and return to the society of other people. The possession that tortured him - that is, his mental illness, his madness - has abated; the Legion of devils has retreated and gone into the small abyss of the lake; "they" have fallen silent; the unclean animal multiplicity has given up its place for the unity of the human "I."

There is something in this biblical miracle of healing akin to psychoanalysis - the science of the unconscious, which Freud linked to the repressed animal element in the human, and Lacan to language, to the unruly speech of the Other. In 1910 a Russian patient, Sergei Pankeev, later known as the Wolf Man, comes to Freud in order to complete a course of therapy and cure himself of his psychic malady. During one of the sessions he tells Freud his childhood nightmare. It is nighttime and the boy (the patient) is lying in his bed. Suddenly the window of his bedroom swings open, and he sees a tree, and on its branches are sitting wolves - several (six or seven) white wolves with bushy tails like fox tails. The wolves sit motionless and stare fixedly at the boy. After this terrifying vision (he is afraid of being eaten by the wolves), the boy wakes.

The patient notes that the only movement in this dream about motionless wolves is the window opening 
before him. A rather significant detail, which allows the patient to understand all at once that it was not the window but his own eyes that suddenly opened before something terrible. In the course of analysis, by means of an inversion, the idea comes up that the fixed stare of the wolves is in fact the boy's own gaze. According to Freud, it is he, the boy, who is looking with wolf's eyes at something frightening in the place where he is supposed to be himself: "The attentive gaze, which in the dream he attributes to the wolves, is actually to be ascribed to him." 15

Interpreting this narrative, Lacan again uses the metaphor of the mirror. The subject's gaze coincides with the place it is directed towards: "The subject passes beyond this glass in which he always sees, entangled, his own image." ${ }^{16}$ Lacan links this unique experience provided by the "navel" of the dream with some ultimate real, emphasizing the fact that the unconscious is not some kind of supplement to the subject but its dissociation, disintegration, disruption. The human subject carries its own rupture within. For the multiplicity of animals, evil spirits, and the abyss is now no longer in some other place but in the human subject itself. The boy is the wolves staring at him with their fearsome eyes. To be precise, they stare at him from the outside (the anonymous multiplicity of the unconscious).

While trying to describe the picture of his dream, the patient cannot remember exactly how many wolves were sitting in the tree. He hesitates - were there seven, six, or

15 Sigmund Freud, From the History of an Infantile Neurosis, in The Wolf Man by The Wolf Man (New York: Basic Books, 1971).

16 The Seminar of Jacques Lacan, Book II: The Ego in Freud's Theory and in the Technique of Psychoanalysis, 1954--5, trans. Sylvana Tomaselli (New York; London: W.W. Norton \& company, 1991), 177 . even five? Freud has an explanation for this uncertainty. No doubt the patient heard from his nanny the popular Russian fairy tale, "The Wolf and the Seven Kids:" the mommy-goat left her seven kids alone one day and went off for milk. While she was gone the wolf got into the house. The kids had time to hide in different places, but the wolf found them anyway and ate them. Only one of them managed to survive - the one hiding in the wall clock. The seventh kid hid and watched the scene of devouring from his hiding place against the wall. And this kid, as we can guess, is the boy himself, as if watching the others (who have now turned into strange wolves, as if they were bitten by a vampire). What follows is an extensive interpretation, in which Freud comes to the conclusion that at the root of this wolf fantasy lies a traumatic episode - a scene of his parents copulating that the patient happened to observe in his very early childhood.

Freud's conclusion has become the butt of endless jokes - especially by Deleuze and Guattari, who dedicated the second chapter of their Thousand Plateaus to the Wolf Man - “1914: One or Several Wolves?” For Deleuze and Guattari Pankeev's dream is the call of the pack, the animal multiplicity of the dreamer's unconscious: "Freud tried to approach crowd phenomena from the point of view of the unconscious, but he did not see clearly, he did not see that the unconscious itself was fundamentally a crowd. He was myopic and hard of hearing; he mistook crowds for a single person." ${ }^{\prime 17}$

With their silence the wolves call the boy to join the pack - to which he may have always belonged in the first place. Their gaze is a call to become one of them, to becoming-

17 Gilles Deleuze and Felix Guattari, A Thousand Plateaus: Capitalism and Schizophrenia, trans. Brian Massumi (Minneapolis: University of Minnesota Press, 2005), 29-30. 
wolf, into which the boy was already being drawn, until his vision turned into a nightmare. Freud, according to Deleuze and Guattari, performs an unforgiveable reduction, substituting the wolves first with kids, sheep, sheep-dogs - in a word, domestic animals - then with the parental couple, and finally with the father. He substitutes the singularity of family history for the wild multiplicity of the pack, step by step reducing the indeterminate number of wolves to one, and then to zero, in order to construct the unity of a normal subject, to construct the false unity of what is in fact an irreducible schizoid multiplicity. Wolves always travel in packs, Deleuze and Guattari remind us - everyone knows this, even a little child knows this, only Freud does not:

We witness Freud's reductive glee; we literally see multiplicity leave the wolves to take the shape of goats that have absolutely nothing to do with the story. Seven wolves that are only kid-goats. Six wolves: the seventh goat (the Wolf-Man himself) is hiding in the clock. Five wolves: he may have seen his parents make love at five o'clock, and the Roman numeral V is associated with the erotic spreading of a woman's legs. Three wolves: the parents may have made love three times. Two wolves: the first coupling the child may have seen was the two parents more ferarum, or perhaps even two dogs. One wolf: the wolf is the father, as we all knew from the start. Zero wolves: he lost his tail, he is not just a castrater but also castrated. Who is Freud trying to fool? The wolves never had a chance to get away and save their pack. ${ }^{18}$

The Wolf-Man keeps howling: Six wolves! Seven wolves!

Freud says, How's that? Goats, you say? How interesting.

18 Deleuze, Guattari. A Thousand Plateaus, 28.
Take away the goats and all you have left is a wolf, so it's your father... ${ }^{19}$

Unlike Freud, Deleuze and Guattari know that a pack cannot be counted. They are fascinated by the beauty and multiplicity of the wolf pack, and they have no concern for family drama or the kid-goats. We cannot agree with these authors, however, when they say that the kids have nothing to do with the story. It is the biblical tradition - to which we are all, analysts and patients, forever in debt - that does not allow us to agree with them. In this tradition goats are specifically unclean animals, linked to evil spirits and even the cult of Satan. What Deleuze and Guattari call a reduction, in slightly other language could sound like a miracle of the psychoanalytic cure. Turning the wolves into fairy-tale kids, Freud literally drives out the demonic wolves that had possessed the patient, sending them into a herd of goats (comparable to the herd of pigs "feeding nigh"), in order finally to make both the demons and the beasts to disappear. There is no place for the animal multiplicity in human society, integration into which is one of the tasks of analysis. The ship of fools must sail off without the Russian boy on board.

How many wolf-kids can fit on this boat? Since the ship of fools is Noah's ark in reverse, nothing prevents us from assuming - employing (not so) free association and inversion - that seven unclean animals climb on board. Freud's seven kids are not the ones taken onto Noah's ark but the ones sent away on the ship of fools or cast into the abyss along with the demonic wolves. The seventh kid (suspended, hiding in the wall clock or on the other side of the bedroom window) is the one who must be sacrificed (perhaps as the cost of success in the psychoanalytic treatment). We recall that among

19 Ibid., 38. 
the unclean animals it is the goats that are traditionally sacrificed, and these goats are called "scapegoats" or expiatory sacrifices. All the sins of a given community are laid upon them, and then they are driven away.

The little wolf-man is not only a man and not only a wolf (wolves) but simultaneously a scapegoat, torn into pieces by the sins (desires, fears) that he embodies, and a little kid, peeking out of his hiding place at all these sins (starting with the famous Freudian primal scene and ending with the devouring of the other kids by the "papa-wolf"), and a little boy, whose gaze not only meets but suddenly coincides with the gaze of the uncountable beasts, who must be driven out, cast into the abyss, into oblivion, if he is to get the unity of human life in exchange. This expiatory sacrifice, described in the language of psychoanalysis in terms of repression, is the cost of being born into the adult individual world. From such units is formed the gathering of people. However we try to build humanity, first there must always be the miracle of exorcizing the demons or, the same thing the nightmare of repression. ${ }^{20}$

However, I understand the thesis of how repression turns the animal (herd-ness, pack-ness) into the human (sociality, adding up one by one) only in a very narrow sense. The animal multitude (the unconscious) does not exist by itself, immediately, before and unrelated to the act of repression, but arises precisely in this mediating act as what immediately returns. As Lacan says:

The trauma, in so far as it has a repressing action, intervenes after the fact [après coup], nachtrâglich. At

20 On the problem of counting beasts in the context of an analysis of these two stories and the case of the Wolf Man, see my article: Oxana Timofeeva, "Chislo zverei," in Lakanaliia 6 (2011), 118-22. this specific moment, something of the subject's becomes detached in the very symbolic world that he is engaged in integrating. From then on, it will no longer be something belonging to the subject. The subject will no longer speak it, will no longer integrate it. Nevertheless, it will remain there, somewhere, spoken, if one can put it this way, by something the subject does not control. ${ }^{21}$

Repression and the return of the repressed are one and the same thing. What returns has never been. Repression engages what has never been, into a kind of active non-being. I am speaking about the negativity of the wolf pack - this is what Deleuze and Guattari would never agree with, since they put the animal multiplicity of the unconscious into the plane of immanence, which knows no non-being (it is well known how negative the attitude of the theoreticians of schizoanalysis was toward negativity - the servant of dialectics).

The wolf pack (the crowd, the animal multiplicity of the unconscious) is not so much a naïve, wild predecessor, as it is an ambiguous fellow-traveller of the human, which condemns it to non-being. These monsters are engendered by the sleep of reason, and this sleep should not be understood metaphorically - as a pause or deactivation of the waking work of thought - but as what Freud called "the other scene" - something that thinks instead of us..$^{22}$ There are no original, natural wolves, calling the boy to return to the pack. It was not just simple wolves that came for him, but cultured, sexual, political wolves. They are complexly organized. "They" think.

21 The Seminar of Jacques Lacan, Book 1: Freud's Papers on Technique 1953--4, trans. John Forrester (London: W.W. Norton \& Company, 1991), 191.

22 See Mazin, Vvedenie v Lakana, accessed November 17,2014. http://www.xliby.ru/kulturologija/vvedenie_v_lakana/p2o. php. 
Yet how should one relate to the assertion of Deleuze and Guattari that wolves always travel in packs? Is it not an exaggeration to examine the animal unconscious exclusively in terms of a multiplicity? Our mythology is filled with lone wolves and she-wolves. The wolf is a veritable symbol of solitude - proud, romantic solitude, or the solitude of the strongest, or the solitude of an overdriven beast. Wolves travel in packs, in the night flashes a multiplicity of evil, yellow eyes, but for some reason our cultural imagination stubbornly rips out a single wolf from this pack. How can a given, concrete, singular individual be a part of a pack? Deleuze answers this question with the words of Franny: "How stupid, you can't be one wolf, you're always eight or nine, six or seven. Not six or seven wolves all by yourself all at once, but one wolf among others, with five or six others." ${ }^{23}$

Let's turn our attention to this "we" of wolves that we are in the schizophrenic experience of the pack. Here there is no I-wolf; we are in a composition of wolves, always immediately the entire pack; we are only ever together with the others, among their number. Offering another example, Franny tells her dream - "a very good schizo dream," as Deleuze characterizes it - about the desert: "There is a teeming crowd in it, a swarm of bees, a rumble of soccer players, or a group of Tuareg. I am on the edge of the crowd, at the periphery; but I belong to it, I am attached to it by one of my extremities, a hand or foot. I know that the periphery is the only place I can be, that I would die if I let myself be drawn into the center of the fray, but just as certainly if I let go of the crowd." ${ }^{24}$

In this description another interesting quality is added to the impossibility of being alone in a pack (Franny is bound

23 Deleuze and Guattari, Thousand Plateaus, p. 29.

24 Ibid. to the desert crowd by her hands and legs, her oneiric "I" is inseparable from the "we" - bees, footballers, or Tuareg people) - peripheralness. We are both in the pack and at its edge. Let's compare this with the description of the pack (this time a human one - for example, a hunting or war party) by Elias Canetti - Deleuze cites him, emphasizing the distinction Canetti makes between a pack and a mass. A person in a mass presses toward the center, he or she is completely dissolved, submitting to the leader of the mass, to its tasks and its goal. The pack, by contrast, is characterized by decentralization, or in Deleuze's words, "is constituted by a line of flight or of deterritorialization." ${ }^{25}$ Every individual in Canetti's pack "will again and again find himself at its edge. He may be in the centre, and then, immediately afterwards, at the edge again; at the edge and then back in the centre. When the pack forms a ring round the fire, each man will have neighbours to right and left, but no-one behind him; his back is naked and exposed to the wilderness." 26

From the perspective of Deleuze and Guattari, the question of one wolf in the pack does not make any sense at all, since for them the wolf is not some individual collection of characteristics but one name for the affect of becoming-wolf; every animal is itself already a pack. An irreducible multiplicity is not a gathering of individual beasts, taken one by one. The irreducible multiplicity means every animal is a pack, among its number.

Nonetheless, Deleuze and Guattari do have a place for a lone wolf - the one who runs alongside and at the same time a bit apart from the main pack. He can be the leader of the pack or an outcast. Deleuze and Guattari call such an animal, which exists in every pack, a demon,

25 Ibid., 32.

26 Elias Canetti, Crowds and Power, trans. Carol Stewart (New York: Continuum, 1981), 93. 
an exceptional individual or an anomaly. And here the theme of the periphery or the border takes on a special significance. The exceptionalness of the individual is determined by its position at the border of the pack (sorcerers, for example, "have always held the anomalous position, at the edge of the fields or woods . . . at the borderline of the village, or between villages, ${ }^{27}$ where they enter into a secret alliance with various animals and demons).

The anomaly is not only at the border; it is the phenomenon of the border itself, of "bordering." 28 In other words, the border of the pack runs through the exceptional individual: "beyond the borderline, the multiplicity changes nature," ${ }^{29}$ crossing over into another dimension. As Catherine Malabou notes, the role of the anomaly is "to mark out the end of a series and the imperceptible move to another possible series, like the eye of a needle of affects, the point of passage, by means of which one motif is stitched to another." ${ }^{\circ}$ This extremely dynamic world of multiplicities and series is measured by intensities of becoming - on the borders of the pack anomalous individuals form alliances, blocks of becoming, of transition.

One should also not forget about sorcery - metamorphoses that occur at the border of the pack, metamorphoses of certain types of animals into others, into monsters. At a certain moment not only the lone wolf appears on the horizon but the werewolf or the

27 Deleuze and Guattari, A Thousand Plateaus, 246.

28 Ibid.

29 Ibid., 245.

30 Catherine Malabou, "Who's Afraid of Hegelian Wolves?," in Deleuze: A Critical Reader (Oxford: Blackwell Publishers, 1996), 128. wolf in sheep's clothing. Let's return to the Wolf Man and have a look at this, using the optics of becoming and transition, how the metamorphosis from one animal series into another takes place in Freud's interpretation. What follows, as mentioned earlier, is significant for its bringing psycho- and schizoanalysis, Freud and Deleuze, together into a paradoxical and unnatural alliance.

So, once again. The seven wolves are the kid-goats (eaten by the wolf). There are six of them because the seventh one hid in the wall clock. I have already drawn a comparison with the vampire bite - the kids eaten by the wolf turn into wolves themselves (contagion is one of the characteristics of a pack). It is clear that the dreamer himself should have been eaten first. But he was able to hide - at the cost of having to observe the bloody massacre of the others.

At this original stage of his interpretation Freud seems to perform a reverse movement, again drawing the little bodies of the kids out of the belly of the demonic wolves, or, more precisely, the belly of one demonic wolf (this time we remember another fairy tale - about Little Red Riding-Hood and the woodsmen, who kill the wolf and free the little girl and her granny, whom he had eaten).

Later we learn that the wolf, having eaten everyone else, is in fact the boy's father. Some kind of strange universal father-mother, who in order to give birth to the boy from his belly must first eat him (or vice versa - but sequence does not matter in the world of the unconscious). Here the patient's recollection of a book illustration that his sister used to scare him with in childhood plays a significant role - a wolf standing on its hind legs and reaching out a forelimb. Note the extraordinary position of this wolf; it is a pose uncharacteristic of his species, standing on the border between two packs - animal and human. 
Thus, before us there are at least three borders between packs, three anomalies - between the wolves and the kids, between the wolf and the human, and also between this monstrous multiplicity of wolf-kids, reduced by Freud to the lonely figure of the father, and the boy himself, who meets it and exchanges gazes with it (there are also intermediary borders, involving sheep, sheepdogs, the spread legs of the mother, and even the wall clock). On which border does our patient find himself? On all three.

However, we should not allow any confusion at these borders. It is not just an undifferentiated animal multiplicity before us, where the fantasies of the child and the hypotheses of the analyst allow easy transformations from one thing into another. The animal multiplicity is not primordial chaos but, as already mentioned, the complexly constructed and difficult to translate language of the Other. Thus, between the wolves and the kids runs a line of tension that separates two animal multitudes not just one pack from another but, let's be clear, a pack from a herd. Deleuze and Guattari are not very interested in this aspect of the situation. In principle, they are indifferent to what parameters, besides intensities and affects, real animals use to organize themselves, so to say, in real life: packs, herds, crowds, colonies - for them all these are nothing more than scientific abstractions, "ridiculous evolutionary classifications." ${ }^{11}$

Meanwhile, I insist that the appearance of herd animals in Freud's interpretation is no accident (although it does seem like one). The difference between a herd and a pack is the difference between those who devour and those who are devoured. It is precisely devouring in the given case that facilitates the transition from one condition into another. The wolf in sheep's clothing is not only an

31 Deleuze and Guattari, A Thousand Plateaus, 240. interloper. There will come a time when he will stand up, straighten his legs, and throw off the sheepskin; at the last moment of their lives, the sheep will encounter the naked king, the father-devourer. The alliance between the wolf, the sheep (the kid-goats), and the father, god, leader, who runs along the borders between pack and herd and between human and animal, remains outside the field of vision of Deleuze and Guattari. For us, however, it is of fundamental importance.

In the beginning of his seminar about the sovereign and the beast, Derrida puts together a fantastic series of different cultural representations of the wolf, setting the stage for his quote from Rousseau's Social Contract (ch. 2): "It is doubtful, then, according to Grotius, whether the human race belongs to a hundred or so men, or if that hundred or so men belong to the human race: and throughout his book he seems to lean toward the former opinion: this is also Hobbes's feeling. So, here we have the human race divided into herds of cattle, each one with its chief who keeps it in order to devour it." 32

It is difficult not to agree that this is one of the most exhaustive descriptions of human communities, where the exceptional position belongs, as Derrida says, precisely to the wolf (who, we should note, intentionally runs across the border between the pack and the herd):

$[\mathrm{H}] \mathrm{e}$, the chief, does not keep the beast by devouring it, while devouring the beast (and we are already in the space of Totem and Taboo and the scenes of devouring cruelty that are unleashed in it, put down, repressed

32 Jean-Jacques Rousseau, Du contrat social (Paris: Classiques Garnier, 1954), 237, cit. by Derrida (quote in Derrida's translation), In: Jacques Derrida, The Beast and the Sovereign, Vol. 1, trans. by Geoffrey Bennington (Chicago: University of Chicago Press, 2009), 11-12. 
in it and therefore displaced in it into symptoms; and the devouring wolf is not far away, the big bad wolf, the wolfs mouth, the big teeth of Little Red Riding Hood's Grandmother-Wolf ('Grandmother, what big teeth you have'), as well as the devouring wolf in the Rig Veda, etc., or Kronos appearing with the face of Anubis devouring time itself). ${ }^{33}$

This Kronos with the face of Anubis, whom Derrida mentions, was time itself, devouring his children. To say that he devours time is an inversion, making time appear to devour itself. He devours his children when they are still infants, fearing the prophecy that one of them will destroy him. In the end, of course, this is what happens: Kronos eats five infants (according to the myth they are Hestia, Demeter, Hera, Hades, and Poseidon); the sixth, Zeus, manages to survive (his mother Rhea goes to Crete and gives birth to Zeus in a cave, slipping Kronos a stone in his place); Zeus overthrows (and in some versions castrates) his father and releases the other devoured children from his belly.

Thus, we have five devoured children, the sixth survived (hidden in a cave). If we are speaking of the same story, dealing with different versions, then there should be a seventh. Who is this seventh? It is Kronos, himself. He is also part of the pack, part of the herd, a member of the family. He is one of us, just like the leader, who worries about the herd in order to devour it, a member of this herd just like the wolf-father - one of the wolves sitting in the tree in Pankeev's dream. The one who devours and the ones who are devoured or sacrificed are reflected in one another.

33 Derrida, The Beast and the Sovereign, 12.
What is the bloody drama enacted at this border - a drama narrated in different languages in legends, fairy tales, and the dreams of little Russian schizophrenics? The drama can take different names - the exorcism of demons, the miracle of healing, the nightmare of repression, or, in the words of Freud, "organic repression," the birth of the one out of the multiple (which never existed before), the child becoming an adult, the formation of human society. And here is the moral of the story: the road to the human runs through the wolf.

Let's clear things up a bit. The fact is that on the level of social being we can always determine who is the oppressor and the devourer and who is the oppressed and the devoured. Our ideas about justice, equality, and liberty, which for this reason lay the foundation for our version of how to rebuild humanity, are all on the surface. Say, we can act in solidarity with the oppressed, the repressed, the devoured. We speak about repression in the context of violent state apparatuses, for example.

But what should we do with the other type of repression? The one that each of us enacts on an individual level even before we are aware of it - perhaps, already at that very moment when we recognize ourselves in the mirror, unlike the pigeons? When, appropriating the image of the other, we send into non-being the animal multiplicity from which the unity of our body is formed? The multiplicity, which never abandoned its non-being, but rather had its non-being actualized, acquiring meaning retrospectively in the very act of repression.

Deleuze and Guattari, as mentioned above, reject the negativity, retrospection, and reflexivity of the pack. They populate the plane of immanence with packs, where one series crosses over into another along the borderlines, guaranteeing ontological continuity. But for them the 
violence practiced in the process of normalization, at the entrance to human society, is clear - the wolves are not allowed to speak, they have no chance. However, for Deleuze and Guattari, it is Freud who is to blame for all of this, himself resembling the papa-wolf, along with the repressive apparatus of psychoanalysis, founded on the almost fascist reduction of multiplicity.

I contend that psychoanalysis plays a somewhat different role here, pinpointing transformations that occur on the border of human society, giving them narrative structure, and thus forcing a certain constitutive act of violence to speak. “They" speak - but "we" don't like it. The analyst is not so much the subject of this act (which Deleuze sees as discursive violence against the patient) but rather its medium, if one can put it this way, the one who translates it into the language of symptoms. It is not immanent borders that divide the Freudian packs but a painful, traumatic rupture. The rupture was there from the beginning - before the one appeared on this side and multiplicity on the other. It is something like a psychoanalytic Big Bang, from which we, they, and our wolves emerge every time.

We cannot simply get up and return to the wolves, who call to us with their silent gaze, unless we want to be known as real schizophrenics and doom ourselves to isolation. Even this strategy cuts both ways, since there is no authentic, primordial pack waiting for the schizophrenic at the end of his journey - every pack has a border and this border is us, not another wolf. We should speak of the exceptional position not as occupied by certain individuals but by everyone in the pack recall how Canetti tells us that one's back is only exposed to something outside of us. From there, from behind our back, we hear the inarticulate speech of the Other.
It is not as if there are some separate, lonely wolves running in the distance who are exceptional (anomalous, to put it in Deleuzian) with regard to the rest, the regular individuals in the pack. All individuals are exceptional, only some, to paraphrase Orwell, are more exceptional than others: the fathers of families, leaders, gods, wolfdevourers in sheep's clothing - these are illustrative models for how each of us integrates into normal human society. In order to get into this society, it is necessary first to become some of it, to complete organic repression, to drive out, devour, or annihilate.

All of us perform this complex sacrifice, however, with natural ease - and this is why we are all already there (here). We have to go through all the stages of becoming at once: the scapegoat, the son, the wolf-father, driving off the pack, devouring the herd (strictly speaking, the pack of other predators is driven off in order to master one's own herd and devour it). Simultaneously there is the return of the repressed, the pack, which must first be driven out in order to return to us again, because we are still among its number, or the return of the herd, which must first be eaten in order to be born again from the belly of the predator. Our pack and our herd - the animal, multiple unconscious - will always run after us and frighten us with their silent call.

But how then, it must be asked, can we rebuild a community based on such human material, in which organic repression at the individual level entails oppression and violence at the level of the social? Is a human community ever possible without immediately turning into a nightmare? It is clear that without the presence of repressed elements no separate adult human and no separate society are possible. But repression means the return of the repressed - in gatherings composed of people one by one, each in the final analysis 
is anxious, tortured, and haunted by the whole pack of those who have been devoured, driven out, crushed, or not taken on board of the ark - because each remains a part of this pack.

Let's now go back to the point where we began, with the formulation of the question about the community as a question of the unconscious and the real of our desire. We did not invent this desire in order to desire it consciously; something desires for us, behind our back. The pack that runs after us wants something from us. They speak, they address us with a call that we interpret either as infantile drives, as unformed, abnormal child sexuality beyond the ego, or as the inarticulate animal cry, howl, or silent call.

The theory of the community that I am suggesting here revolves around these shadows that follow us, trying to look behind our back. Unconscious desire for communism is probably not the best name for it, but I haven't thought of anything better. Between us, all three of these words are dubious - unconscious, desire, communism. All three are problematic, ambivalent. But in any case this triad is preferable to, say, consciousness, interest, and capitalism (or various others), since it hints at a non-human community. It reminds us of what has not yet been. Of communism with a non-human face.

Jodi Dean writes: "The communist horizon is not lost. It is Real," ${ }^{34}$ while also, by the way, associating the desire for communism with the unconscious. It is precisely in this sense that she calls it Real: not real communism (as we are accustomed to speak, for example, of "really existing socialism"), but communism as the Real, in the Lacanian sense, as a certain traumatic excess that resists symbolization, which can in no way be confused with reality. The Real of desire does not coincide with those desires that we recognize in ourselves - it stands behind us, just like the horizon of communism, which has never been, behind our back. It stands directly behind our back, right there, forming a border between what has been and what has not. It is as if we have grown into this horizon with our backs, and we are the border ourselves.

Like Jodi Dean, I speak of the Real of the horizon and of the desire for communism, but I want to follow this desire all the way to the level of the unconscious, the animal. One would object, animals do not have an unconscious, and thus they cannot have the Real of desire - they have only drives. That's just the point. As mentioned above, they, our pack and our herd, live in principle for "being" instead of "having," in other words, they are the unconscious, they are the desire for communism, which exists nowhere in nature, not in the plane of immanence, not among real wolves; but this "not" precisely indicates the negative character of desire, in this "not" we hear that "not yet" and "still not yet" that troubles us so (by the way, in Pankeev's second dream about wolves, analyzed by Freud's student Ruth Mack Brunswick, these animals, again scaring the dreamer, are associated with the Bolsheviks).

Let's replace the plane of immanence with the plane of retrospection, from which the wolves are breathing on our backs. Our desire will be there, in that forgotten pack, which arose along with us and immediately stuck to us. What they want from us is the real of our desire, and this is where we should begin, when we ask the question about the community. "You send sailors on a sinking cruiser to a place where a forgotten kitten mewed,"

34 Jodi Dean, The Communist Horizon (London; New York:

Verso, 2012),11. 
writes Mayakovsky about the revolution, ${ }^{35}$ and I cannot imagine a better image for the program of communism with a non-human face. The community is not for us but for them; it is redemption, a turn, a reactivation of animal negativity - this is the task, and its absurdity is why it really deserves serious discussion, and I hope that sooner or later this discussion will take place.

Translated by Jonathan Brooks Platt 